\title{
Video-Based Learning about the Effect of Various Types of Flour on the Characteristics of Sagon Crackers for High School Students
}

\section{Sri Anggraeni, Silmi Aulia Rohmah, Silmi Ridwan Putri, Risti Ragadhita, Siti Nur Hofifah, Asep Bayu Dani Nandiyanto}

Universitas Pendidikan Indonesia, Jl. Dr. Setiabudi No. 229 Bandung, Indonesia

anggraeni_said@upi.edu,nandiyanto@upi edu, silmiaulia38@upi.edu, silmiridwanppp@upi.edu, ristiragadhita@upi.edu, sitinurhofifah@upi.edu, nandiyanto@upi.edu

\begin{abstract}
This study aims to present learning about the characteristics of sagon crackers through video learning media for high school students. Sagon crackers are made by varying the flour (sago flour, a mixture of sago flour with maize, a mixture of sago flour and wheat flour, and a mixture of sago flour with tapioca flour). Sagon crackers are made by mixing the ingredients then molding the dough in the oven $\left(150^{\circ} \mathrm{C}\right.$ for 15 minutes). Several series of tests such as puncture test and hardness test are conducted. This research is conducted by providing pretest questions, video learning, and posttest questions. The results show that each sagon crackers has a different appearance. This is because of the difference in protein content; the lower the protein in the texture crackers, the harder the texture of the crackers. Meanwhile, based on the test results on high school students show that the use of video learning media can increase student knowledge. According to the t-test results, video learning media has a significant effect on student learning outcomes. Based on the test results obtained, this study can assist in the selection of instructional media for students and can find out the various characteristics of sagon crackers.
\end{abstract}

Keywords: Crackers, Variations of Flour, Learning media

Asep Bayu Dani Nandiyanto

Universitas Pendidikan Indonesia, Jl. Dr. Setiabudi

No. 229 Bandung, Indonesia

nandiyanto@upi.edu

\section{Introduction}

Education is a continuous practice which consists of a structured learning process that is directed individually or socially (Sarid, 2017). Educational media plays an important role in the learning process. The use and selection of one teaching method have consequences on the use of an appropriate type of learning media (Ramdhani, Muhammad, and Hilmi, 2015). One of the learning media that can be used is video-based learning media. Video-based learning media can increase the retention rate (memory) of students towards the material presented (Puspitarini, Akhyar, and Djono, 2018). It can also increase student's interest in subject matters, the motivation of learning, and lead to better learning outcomes (Zhang, Zhou, Briggs, and Nunamaker, 2006), and create a pleasant atmosphere and a meaningful learning environment for students (Sulihin, Asbar, and Elihami, 2020). One example of using video-based learning media is video-based learning for elementary school students (Puspitarini, Akhyar, and Djono 2018), foreign language learning (Secules, Herron, Tomasello, 1992), and curriculum learning 2013 (Hasan, 2017). Meanwhile, video lessons on the analysis of food characteristics, especially the characteristics of crackers, are rarely found.

Crackers products are more popular because of their existence, long shelf life and good sensory properties (Onacik-Gür and Żbikowska, 2020). One of the typical pastries in Indonesia is sagon crackers. Sagon crackers are generally made from desiccated coconut (DC), rice flour, sugar, and salt (Ghani, Yusof, Talib, Chin, and Aziz, 2012). Currently, there are many variations of sagon crackers, one of which is the composition. The composition variance given to the making of sagon crackers can affect the characteristics of sagon crackers. 
In Indonesia, sagon crackers have been processed into various processed products with a variety of compositions. As an example, sagon crackers made from cassava flour (Kamsiati, and Herawati, 2019). Variations in the composition, especially flour can affect the characteristics of sagon crackers. So, it is necessary to understand the characteristics of sagon crackers based on variations of flour. Therefore, the novelty of this study is the presentation of learning about food characteristics, especially sagon crackers through video learning media for high school students. This research is expected to help as a reference regarding the characteristics of food (sagon crackers) and video-based learning media for students.

\section{Method}

\subsection{The Making of Sagon Crackers}

This research starts with the making of sagon crackers. The ingredients for making sagon crackers are obtained from the Cianjur market, Indonesia. There are some stages in the production process of sagon crackers. Frst, the flour and coconut are sprinkled. It is then roast to remove the water content and bring out the fragrant aroma of flour and coconut After that, the roasted coconut is mixed with eggs, sugar, vanilla, and flour. The sagon crackers production is made by varying the composition of the flour ingredients. There are four variations of flour, namely sago flour (SF), a mixture of sago flour with maize (SF: MF), a mixture of sago flour and wheat flour (SF: WF), and a mixture of sago flour with tapioca flour (SF: TF). The composition of the various flours is summarized in Table 1. After all the ingredients are mixed, the dough is then molded and put in the oven at $150^{\circ} \mathrm{C}$ for 15 minutes.

Table 1. The composition of the sagon crackers.

\begin{tabular}{|l|c|c|c|c|}
\hline Composition & SF & SF:MF & SF:WF & SF:TF \\
\hline Flour (g) & 200 & $100: 100$ & $100: 100$ & $100: 100$ \\
\hline Egg (grain) & 1 & 1 & 1 & 1 \\
\hline Vanilla (g) & 2 & 2 & 2 & 2 \\
\hline Sugar (g) & 100 & 100 & 100 & 100 \\
\hline Coconut (g) & 250 & 250 & 250 & 250 \\
\hline Coconut milk (g) & 65 & 65 & 65 & 65 \\
\hline
\end{tabular}

\subsection{Testing the characteristics of sagon crackers}

Several testing methods are conducted as follows.

1) The Puncture Test: The puncture test is a simple test to measure or determine the texture of many different foods. In this study, the puncture test is conducted by testing the four variations of sagon crackers using the Shore Durometer (Shore A Hardness, In size, China) instrument.

2) The Hardness Test: Hardness test is a mechanical test for material properties used in structural analysis and material development. In this study, the hardness test was carried out by testing the four variations of sagon crackers using a Screw Stand Test Instrument (Mode I ALX-J, China) equipped with a measuring instrument (a Digital Force Gauge (Model HP500, Serial No. H5001909262)). The hardness test is performed by applying a compressive force to each sagon cracker.

\subsection{Teaching Method}

As for study on video learning media, there are 21 participants who participate from a high school in Cianjur, Indonesia. Participants are female and come from 11th-grade science students. The learning is divided into three stages. the first stage is the pretest which consists of filling out the identity, the IQ score, and the questions regarding the sagon crackers. The second stage is giving the learning video about sagon crackers, and the last stage is the posttest which consists of students' identity, IQ score, and posttest questions about sagon crackers. To analyze the learning outcomes, we use t-test.

\section{Results and Discussion}

\subsection{Physical appearances of sago crackers}

The results of sago crackers with four kinds of composition variations are presented in Figure 1. Fig. 1(a) $\mathrm{SF}$, (b) SF:MF, (c) SF:WF, (d) SF:TF, (e) SF (6 x $2.8 \mathrm{~cm}$ ), (f) SF:MF $(4 \times 3.5 \mathrm{~cm}),(\mathrm{g}) \mathrm{SF}: \mathrm{WF}(3.5 \times 3.3 \mathrm{~cm})$, and (h) $\mathrm{SF}$ : TF $(4 \times 2.2 \mathrm{~cm})$.

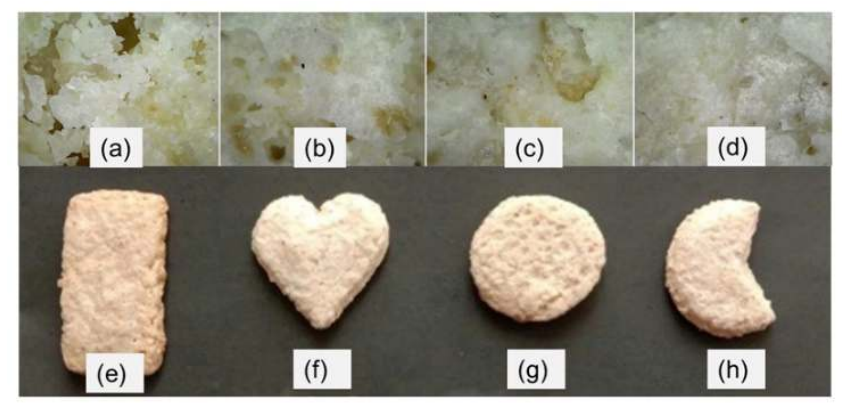

Fig. 1(a-d) microscopy results of sagon crackers with flour variations (SF; SF:MF; SF:WF; and SF:TF), and 1. (e-h) sagon crackers with flour variations (SF; SF:MF; SF:WF; and SF:TF)

\subsection{Characteristics of sagon crackers: Puncture Test and Hardness Test}

Compositions in the material influencedthe mechanical properties of the material (Nandiyanto, Fiandini, Ragadhita, Sukmafitri, Salam, and Triawan, 2020). This makes the need for analysis of the mechanical properties of sagon crackers.

The results of skewering observations on the characteristics of the sagon crackers is shown in Table 2. SF sagon crackers have an average value of 86.20, SF:MF sagon crackers have an average value of $76.40, \mathrm{SF}: \mathrm{WF}$ sagon crackers have an average value of 63.00 , and sagon crackers SF:TF have an average value of 58.00. The highest skewer test value result is on sagon crackers with SF:MF flour variations, while the lowest value is on sagon crackers with $\mathrm{SF}$ variations.

The results of the hardness test conducted on four variations of the composition. Figure 2 shows the hardness test value. The lowest value is sago starch crackers: maize (SF:MF), while the highest hardness test is sago flour sagon crackers (SF). 
The results of the puncture test and the hardness test show that the characteristics of the sagon crackers are influenced by the flour variant. Sagon crackers with single sago flour tend to have a low puncture test value and a high hardness test value. In contrast, sagon crackers with a mixture of sago starch: maize (SF:MF) have a high puncture test value and a low hardness test value. The difference in value between the flour's variants can be caused by differences in protein content. The protein content of sago flour is $0.19-0.25 \%$ (Konuma, Rolle, and Boromthanarat, 2012), maize is $8-12 \%$ (Bonea, 2020), flour is 8\% (Tjokrokusumo, Octaviani, and Saragih, 2019), and the tapioca flour is $0.51 \%$ (Mishra and Rai, 2006). Differences in protein content also affect gluten content. Gluten is the main structure-forming protein in flour, and responsible for the elastic and extensible properties needed to produce a good quality product. (Gallagher, Gormley, Arendt, 2003). High protein is strongly waterbinding, and thus minimized moisture migration to the crust, and create a minimal effect crust hardness on sagon (Gallagher, Gormley, Arendt, 2003). Sagon crackers have a high level of hardness due to the low amount of protein and gluten which results in a hard texture of sagon crackers.

Table. 2 Puncture test results on sagon crackers

\begin{tabular}{|c|c|c|c|c|}
\hline & SF & SF:MF & SF:WF & SF:TF \\
\hline & 45.00 & 75.00 & $59 / 00$ & 55.00 \\
\hline & 52.00 & 71.00 & 64.00 & 65.00 \\
\hline & 56.00 & 72.00 & 63.00 & 52.00 \\
\hline & 62.00 & 67.00 & 72.00 & 57.00 \\
\hline Average & 53.75 & 71.25 & 64.50 & 57.25 \\
\hline
\end{tabular}

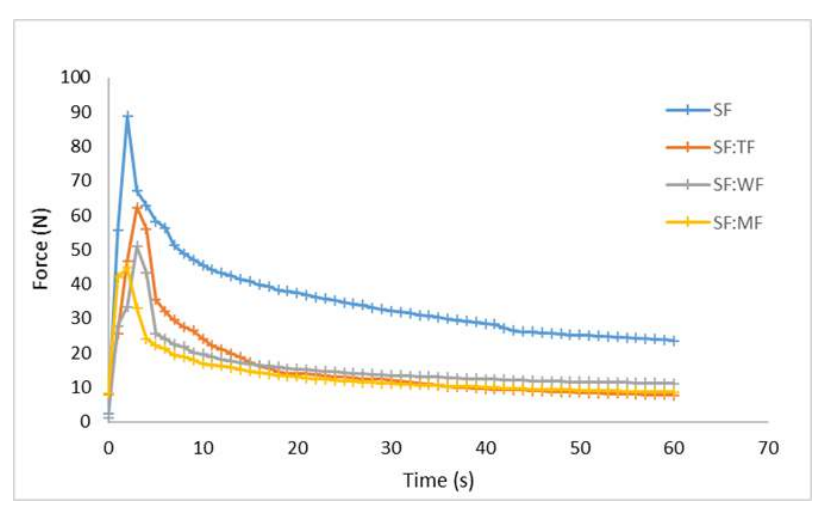

Fig. 2 Graph of hardness test results

\subsection{Learning Outcomes Analysis}

\subsubsection{IQ}

Based on the respondent's IQ score, it is divided into 7 categories, namely intellectually impaired $(<69)$, borderline (10-79), below average (80-89), average (90-109), above average (110-119), superior (120-129), and very superior (>130) (Marusiak and Janzen, 2008). Table 3 displays that there are no students with intellectual impairments, $4 \%$ (1 student) are at the borderline, below average 19.04\% (4 students), average $23.80 \%$ (5 students), above average $19.04 \%$ (4 students), superior $28.57 \%$ (6 students), and very superior $4 \%$ ( 1 student).

Table 3. Student IQ data

\begin{tabular}{|c|c|c|c|}
\hline IQ & Category & Students & $\begin{array}{c}\text { Percentage } \\
(\mathbf{\%})\end{array}$ \\
\hline$<69$ & $\begin{array}{c}\text { Intellectually } \\
\text { impaired }\end{array}$ & 0 & 0 \\
\hline $70-79$ & Borderline & 1 & 4 \\
\hline $80-89$ & Below average & 4 & 19.04 \\
\hline $90-109$ & Average & 5 & 23.80 \\
\hline $110-119$ & Above average & 4 & 19.04 \\
\hline $120-129$ & Superior & 6 & 23.80 \\
\hline$>130$ & Very superior & 1 & 4 \\
\hline
\end{tabular}

\subsubsection{Pretest-posttest analysis results}

Table 4. illustrates the results of student learning through the pretest and posttest. The pretest and posttest questions consisted of 10 true-false questions as a parameter of student learning progress towards video learning media on the characteristics of sagon crackers for high school students.

Table 4 displays that these questions are given to ensure the level of understanding of students during the learning process through video learning media. Table 4 shows that the average student learning outcomes have increased significantly. Video-based learning media can increase student's interest in subject matters, the motivation of learning, lead to better learning outcomes (Zhang, Zhou, Briggs, and Nunamaker, 2006), create a pleasant atmosphere and a meaningful learning environment for students (Sulihin, Asbar, and Elihami, 2020). The t-test results show that video learning media has a significant effect $(\rho<0.05)$ on student learning outcomes $(\rho=0.0055)$.

Table 4. Student pretest-posttest data

\begin{tabular}{|c|c|c|c|}
\hline No & Question & Pretest & Post test \\
\hline 1 & $\begin{array}{l}\text { The largest sago producing } \\
\text { area in Indonesia is Papua }\end{array}$ & 90.47 & 100.00 \\
\hline 2 & $\begin{array}{l}\text { Is sago production less than } \\
\text { the total consumption }\end{array}$ & 57.14 & 33.33 \\
\hline 3 & $\begin{array}{l}\text { Sagon is one of the hard } \\
\text { textured food preparations } \\
\text { derived from sago flour }\end{array}$ & 76.19 & 90.47 \\
\hline 4 & $\begin{array}{l}\text { The most abundant substance } \\
\text { in sago is a protein }\end{array}$ & 33.33 & 19.04 \\
\hline 5 & $\begin{array}{l}\text { Fat content contained in food } \\
\text { affects the sweetness level of } \\
\text { the food. }\end{array}$ & 23.80 & 14.28 \\
\hline 6 & $\begin{array}{l}\text { Is the carbohydrate content in } \\
\text { sago more than that in rice? }\end{array}$ & 57.14 & 85.71 \\
\hline 7 & $\begin{array}{l}\text { Lack of } \\
\text { consumption/utilization of } \\
\text { sago in Maluku is because } \\
\text { sago is not filling }\end{array}$ & 38.09 & 14.28 \\
\hline 8 & $\begin{array}{l}\text { Low protein in sago is a } \\
\text { factor that causes processed } \\
\text { foods made from sago flour } \\
\text { to tend to be tougher than } \\
\text { other flour? }\end{array}$ & 47.61 & 66.67 \\
\hline 9 & $\begin{array}{l}\text { Carbohydrates affect the } \\
\text { sweet taste of food }\end{array}$ & 85.71 & 80.85 \\
\hline
\end{tabular}




\begin{tabular}{|l|l|c|c|c|}
\hline 10 & $\begin{array}{l}\text { Savory taste in food is } \\
\text { influenced by the fat } \\
\text { contained in it. }\end{array}$ & 76.19 & 90.47 \\
\hline & Average & $\mathbf{6 8 . 0 9}$ & $\mathbf{7 9 . 5 2}$ \\
\hline
\end{tabular}

\section{Conclusion}

The presentation of learning about the characteristics of food, especially sagon crackers through video learning media for high school students has been studied. Sagon crackers with a variety of flour which has different ingredients due to differences in protein content. The lower the protein in the sagon crackers, the harder the texture of the crackers, and vice versa. The results of examiners on students show that the use of video learning media can increase student knowledge. The video learning media about the effect of wheat flour on sagon crackers is successful and can be applied in schools. So, from the test results obtained, this study can help in the selection of instructional media for students and can find out the various characteristics of sagon crackers.

\section{Acknowledgements}

This study acknowledged RISTEK BRIN for Grant-in-aid for Penelitian Terapan Unggulan Perguruan Tinggi (PTUPT). We would like to thank the Universitas Pendidikan Indonesia for supporting this study.

\section{References}

Bonea, D. (2020). Phenology, yield and protein content of maize (zea mays 1.) hybrids as affected by different sowing dates. Scientific Papers: Management, Economic Engineering in Agriculture and Rural Development, 20(3), 145-150.

Gallagher, E., Gormley, T., and Arendt, E. (2003). Crust and crumb characteristics of gluten free breads. Journal of Food Engineering, 56 (2003), 153-16.

Ghani, N., Yusof, Y., Talib, R., Chin, N., and Aziz, M. (2012). Changes of physical properties during microwave processing of sagon. Journal of Food Processing and Preservation, 38(3). 758-767.

Hasan, I. (2017). Contextual video: Critical thinking-based learning media in the implementation of curriculum 2013. Dinamika Pendidikan, 12(2), 136-147.

Kamsiati, E., and Herawati, H. (2019). Effect of process parameters to the characteristics of cassava rice sagon. IOP Conference Series: Earth and Environmental Science, Volume 443, 012035.

Konuma, H., Rolle, R., and Boromthanarat, S. (2012). Adding value to underutilized food resources: substituting wheat flour with sago starch in cookie formulations. Journal of Agricultural Technology, 8(3), 1077.

Marusiak, C., and Janzen, H. (2008). Ability and achievement variables in average, low average, and borderline students and the roles of the school psychologist.
The Alberta Journal of Educational Research, 54 (4), 432447.

Nandiyanto, A. B. D., Fiandini, M., Ragadhita, R., Sukmafitri, A., Salam, H., and Triawan, F. (2020). Mechanical and biodegradation properties of cornstarchbased bioplastic material. Materials Physics and Mechanics, 44, 380-391.

Mishra, S., and Rai, T. (2006). Morphology and functional properties of corn, potato, and tapioca starches. Food hydrocolloids, 20(5), 557-566.

Onacik-Gür, S., and Żbikowska, A. (2020). Effect of higholeic rapeseed oil oleogels on the quality of short-dough biscuits and fat migration. Journal of food science and technology, 57(5), 1609-1618.

Puspitarini, Y. D., Akhyar, M., and Djono, D. (2018). Developing powtoon-based video learning media for five grade students of elementary school. International Conference of Communication Science Research, 165, 173177.

Ramdhani., Muhammad Ali., and Hilmi Muhammadiyah. "The criteria of learning media selection for character education in higher education." (2015): 174-182.

Sarid, A. (2018). A theory of education. Cambridge Journal of Education, 48(4), 479-494.

Secules, T., Herron, C., and Tomasello, M. (1992). The effect of video context on foreign language learning. The Modern Language Journal, 76(4), 480-490.

Sulihin, S., Asbar, A., and Elihami, E. (2020). Developing of instructional video media to improve learning quality and student motivation. Edumaspul: Jurnal Pendidikan, 4(2), 5155 .

Talib, C. A., Ali, M., Zawadzki, R., Baharuddin, N. S., Thoe, N. K., and Aliyu, H. (2017). Video-based learning in chemistry educatideeeon: Exemplars, issues and challenges. Seameo Recsam, (12), 35-51.

Tjokrokusumo, D., Octaviani, F. C., and Saragih, R. (2019). Fortification of mung bean (Vigna radiata) and Ear mushroom (Auricularia auricula-judae) in dried sago noodles. Journal of Microbial Systematics and Biotechnology, 1(2), 34-40.

Zhang, D., Zhou, L,. Briggs, R,. and Nunamaker, J. (2006). Instructional video in e-learning: Assessing the impact of interactive video on learning effectiveness. Information \& Management, 43(1), 15-27. 